\title{
The effect of multi-phase injection on selected parameters of the common rail fuel system
}

\begin{abstract}
The common rail fuel supply systems due to their flexibility of injection characteristics are the most frequently applied fuel supply solution in Diesel engines. The most essential parameters, which have the effect on the phenomena taking place in a Common Rail system are the duration of the injection, rail pressure and fuel temperature. There may also be other factors effecting the course of the injection. The split of the fuel dose into a few parts can cause a pressure fluctuation in the rail and also in the whole system, effecting the course of the injection. In the article tests results related with the influence of multiple injection on the total fuel dose and real onset of the injection have been presented. The tests were carried out on a test stand fitted with Bosch EPS-815 (electronic fuel dose measurement). For the testing of the real injection onset the visualization system AVL Visioscope was used. The control of the injector was realized through a controller which enabled to split the fuel dose into three parts.
\end{abstract}

Key words: common rail, fuel injection, injection control, injection pressure, fuel dose

\section{Wpływ wielofazowości wtrysku na wybrane parametry systemu zasilania common rail}

\begin{abstract}
Zasobnikowe uktady zasilania common rail, ze względu na swoja elastyczność w kształtowaniu charakterystyki wtrysku, sa obecnie najczęściej stosowanym rozwiąaniem układów zasilania silników wysokoprężnych. Najistotniejszymi parametrami wptywajacymi na zjawiska zachodzace $w$ takich układach sq czas wtrysku, ciśnienie paliwa w szynie oraz temperatura paliwa. Na przebieg procesu wtrysku wptywaja także inne czynniki. Podziat dawki na kilka części może powodować pulsacje ciśnienia w zasobniku $i$ w catym układzie, wptywając na przebieg tego procesu. W artykule przedstawiono wyniki badań wpływu wielofazowości wtrysku na wielkość sumarycznej dawki paliwa oraz rzeczywisty poczatek wtrysku. Badania prowadzono na stanowisku badawczym wyposażonym w stót probierczy Bosch EPS-815 z elektronicznym pomiarem dawki paliwa, a do określania rzeczywistego początku wtrysku wykorzystano system wizualizacyjny AVL Visioscope. Sterowanie wtryskiwaczem realizowano za pomoca opracowanego sterownika umożliwiajacego podziat dawki na trzy części.
\end{abstract}

Słowa kluczowe: common rail, wtrysk paliwa, sterowanie wtryskiem, ciśnienie wtrysku, dawka paliwa

\section{Introduction}

Because the Euro emission standards are very strict, the fuel systems have to be very precise in their operation. Then, the course of the injection depends on many phenomena occuring in the whole system.

The designers of compression ignition engines have to live up to the challenge resulting from the need to limit the fuel consumption while simultaneously saving high dynamic parameters of the engine. Currently, due to the flexibility of the injection characteristics, common rail systems are the most frequently applied fuel supply systems in Diesel engines [7].

The possibility of realization of a multitude of injections during the same work cycle allows a free control of the course of injection but at the same time it results in issues related to the interaction between the injections. It particularly concerns a situation when the injections are located close to one another. The most essential parameters effecting on the dosage precision are the duration of the injection, the rail pressure and the fuel temperature. While the duration of the injection can be precisely controlled by a system controller, the fuel pressure and the fuel temperature change dynami-

\section{Wstęp}

Zmniejszające się w kolejnych normach Euro limity dotyczące emisji zanieczyszczeń z silników wymagają od układów zasilania dużej precyzji kształtowania charakterystyki wtrysku, która uwarunkowana jest wieloma zjawiskami zachodzącymi w całym układzie. Przed konstruktorami wysokoprężnych silników spalinowych stoją wyzwania wynikające z konieczności zapewnienia zmniejszenia zużycia paliwa i jednocześnie zachowania wysokich parametrów dynamicznych jednostki napędowej. Obecnie najczęściej stosowanym rozwiązaniem układu zasilania silników wysokoprężnych są zasobnikowe układy typu common rail, ze względu na swoją elastyczność w kształtowaniu charakterystyki wtrysku [7].

Możliwość realizacji wielu wtrysków w czasie jednego cyklu pracy pozwala na elastyczne kształtowanie charakterystyki wtrysku, ale jednocześnie powoduje powstawanie nowych problemów związanych z wzajemnym oddziaływaniem kolejnych wtrysków, zwłaszcza w sytuacji, gdy występują one w niewielkich odległościach kątowych. Najistotniejszymi parametrami wpływającymi na dokładność dawkowania są: czas wtrysku, ciśnienie paliwa w szynie oraz temperatura 
cally effecting on the whole injection process and the fuel dose and thus on all the engine parameters $[1,3]$.

In the article the effect of a multi-phase injection on the course of the injection process has been presented. Keeping a constant total injection duration and the fuel temperature, the injected fuel dose and the actual onset of the injection were measured. High-speed processes (the fuel pressure changes in the injection pipe behind the fuel rail and before the injector) and the injector control signals were recorded as well. In this scope the demonstration test results have been presented. The tests were conducted on a test stand equipped with a Bosch EPS-815 (electronic fuel dose measurement). For the testing of the actual onset of the injection the visualization system AVL Visioscope was used.

\section{Test stand and measurement methodology}

The basic elements of the test stand during the tests were as follows: test bench with a fuel dose measurement system with a heat exchanger, high pressure rail and electronically controlled injector. The fuel was injected into a special fuel chamber which enabled the observation of the injected fuel spray. With the use of the visualization system AVL Visioscope the fuel injection into the measuring chamber was filmed. It was realized at $0.1^{\circ}$ angle resolution of the pump shaft. The schematics of the test stand has been shown in Fig. 1.

The description of the fuel dose depending on its splitting strategy was the fundamental aim of the tests. The distances between the onsets of the injector control signals as well as the injection durations were changed. Tests have been conducted for doses splitting into two parts (pilot dose and main dose). The adjusted total injection duration Tinj was 1.0 and 3.0 ms depending on the test program. The injection duration should be construed as a duration of the control signal used for the injector opening. The distances between the onsets of the control signals are adjustable parameters and shouldn't be identified as the real injection onsets. The issues connected with multi-phase injection and actual injection onsets is a continuation of the tests presented in papers $[2,4,5,6,8]$.

Each series of tests were performed at a constant injected fuel temperature $\mathrm{T}_{\mathrm{inj}}$, paliwa. O ile czas wtrysku może być dokładnie kontrolowany przez sterownik układu, o tyle ciśnienie i temperatura paliwa panujące w układzie zmieniają się dynamicznie, wpływając na wielkość dawki i całą charakterystykę wtrysku, a tym samym na parametry silnika $[1,3]$.

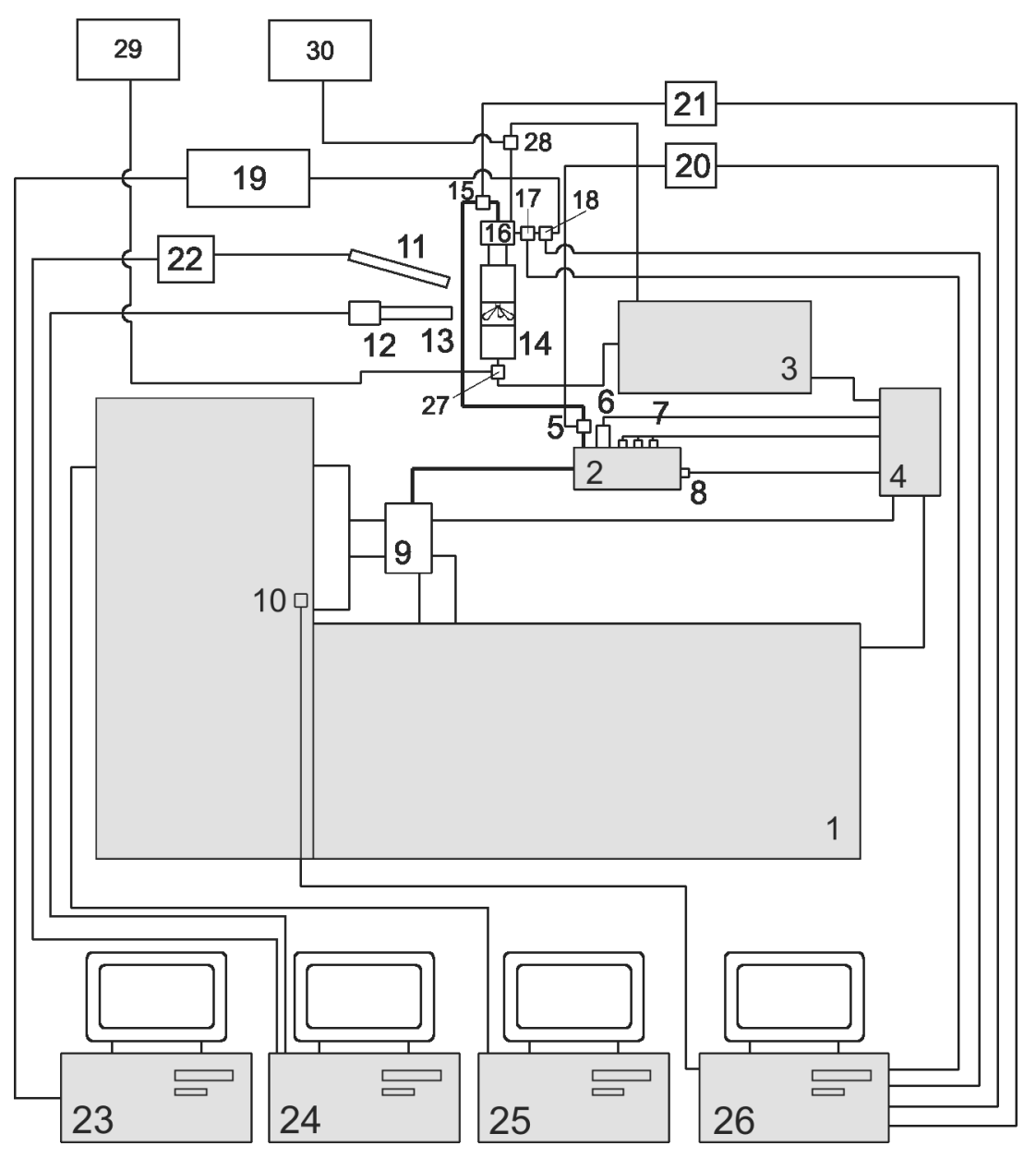

Fig. 1. Schematics of the test stand: 1 - test bench Bosch EPS 815, 2 - rail of high pressure, 3 - fuel dose measurement set Bosch KMA 822 with heat exchanger, 4 - control module of high-pressure pump, 5, 15 - piezoresistive pressure sensors, Kistler 4067A2000, 6 - rail pressure sensor, 7 - rail pressure regulators, 8 - fuel temperature sensor, 9 - high pressure pump 10 - optical position and speed sensor of the pump shaft AVL 365C, 11 - light pipe, 12- digital camera PixelFly VGA, 13 - endoscope, 14 - visualization chamber, 16 - tested injector, 17 - measurement connector of injector control voltage, 18 - injector current sensor PA-55, 19 - microprocessor controller of injector, 20, 21 - charge amplifiers AVL 3057-A01, 22 - light unit, 23 - computer with control software of the injector, 24 - visualization system AVL Visioscope, 25 - computer with software for test bench control and measurement of the fuel dose, 26 - computer with data acquisition devices for high-speed processes recording, 27, 28 - temperature sensors, 29, 30 - thermometers EMT 101

Rys. 1. Schemat stanowiska badawczego: 1 - stót probierczy Bosch EPS 815, 2 -zasobnik wysokiego ciśnienia, 3 - zespót pomiaru dawki paliwa Bosch KMA 822 z wymiennikiem ciepła, 4-modut sterowania pompa wysokiego ciśnienia, 5,15-piezorezystywne czujniki ciśnienia Kistler 4067A2000, 6 - czujnik ciśnienia w szynie, 7 - zespót regulatorów ciśnienia w szynie, 8 - czujnik temperatury paliwa, 9-pompa wysokiego ciśnienia, 10 - optyczny czujnik położenia i prędkości obrotowej wałka pompy AVL 365C, 11 - świattowód, 12 - kamera cyfrowa PixelFly VGA, 13 - endoskop, 14 - komora wizualizacyjna, 16-badany wtryskiwacz, 17 -złacze pomiaru napięcia sterującego wtryskiwaczem, 18 - czujnik prądu wtryskiwacza PA-55,

19 - mikroprocesorowy sterownik wtryskiwacza, 20, 21-wzmacniacze ładunku, 22-modut światła, 23 - komputer z oprogramowaniem sterujacym praca wtryskiwacza, 24 - system wizualizacyjny AVL Visioscope, 25 - komputer z oprogramowaniem do sterowania stolu probierczego i zespołu pomiaru dawki, 26 - komputer z karta pomiarowa do rejestracji przebiegów szybkozmiennych, 27,28 - czujniki temperatury, 29, 30-termometry EMT 101 
fuel pressure $p$ in the rail and frequency of the operation of the injector. A frequency of the operation of the injector resulted from the speed $\mathrm{n}$ of the pump shaft.

The parameter values related to the fuel injection have been shown in the figures presenting the test results. The symbols describing the injection strategy have been shown in Fig. 2.

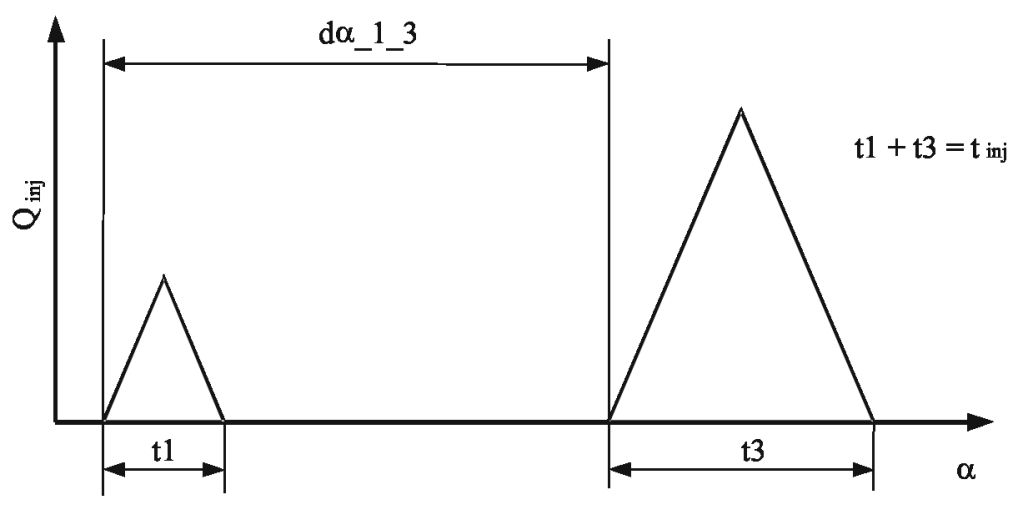

Fig. 2. Symbols describing the injection strategy

Rys. 2. Schemat przyjętych oznaczeń parametrów strategii wtrysku

Based on the analysis of the filmed injection courses in the measuring chamber the actual injection onsets were described with high precision. For a two-phase injection the changes of the actual injection onset for the main dose have been determined referred to the actual injection onset for the single-phase injection (only the main dose). In Fig. 3 the images of the injected stream have been presented.

During the tests the injectors by Bosch fitted in the engine of Renault G9T (marked 445010 343-01) and those fited in Fiat Multijet 1.3 (marked 445010 083) were used. These injectors worked with a high-pressure pump which is used in the said engines - CR/CP1S3/L70/10-1V and CR/ CP1K3/R55/10-S respectively. The injectors were controlled by a controller developed by the Department of Automotive Vehicles and Internal Combustion Engines that enabled to split the fuel dose and change their angle in a wide range. A detailed description of the controller and the injection system have been presented in work [1].

\section{Test results}

In Fig. 4 and 5 the influence of the distance between the onset of the pilot injection and the start of the main injection $\mathrm{d} \alpha \_1 \_3$ on the fuel dose Qinj at various rail pressures prail and at the pump speed $n=600 \mathrm{rpm}$ has been presented. In this case due to the split of the fuel dose into two parts, the total injection duration amounted $1.0 \mathrm{~ms}$ (pilot dose $0.5 \mathrm{~ms}$ and the main dose $0.5 \mathrm{~ms}$ ). For the injector fitted in Renault (Fig. 4), the largest dose fluctuations appear for shorter intervals between the doses and lower pressures. For two different angle intervals between the pilot dose and the main dose $\left(15^{\circ}\right.$ and $\left.20^{\circ}\right)$ at the rail pressure of $75 \mathrm{MPa}$ the difference between the obtained dose values amounted to more than $10 \mathrm{~mm}^{3}$ /injection (Fig. 4). A little smaller changes of the dose are obtained for the injector fitted in Fiat (approximately
W niniejszym artykule zaprezentowano wpływ wielofazowości wtrysku na przebieg procesu dawkowania paliwa. Przy zachowaniu stałego sumarycznego czasu oraz temperatury wtryskiwanego paliwa mierzono wielkość wtryskiwanej dawki oraz rzeczywisty początek wtrysku. Rejestrowano także przebiegi szybkozmienne (ciśnienia paliwa w przewodzie wtryskowym za szyną i przed wtryskiwaczem) oraz sygnały sterujące wtryskiwaczem. $\mathrm{W}$ tym zakresie zaprezentowano w niniejszym artykule przykładowe wyniki pomiarów. Badania prowadzono na stanowisku badawczym wyposażonym w stół probierczy Bosch EPS-815 z elektronicznym pomiarem dawki paliwa. Do określania rzeczywistego początku wtrysku wykorzystano system wizualizacyjny AVL Visioscope.

\section{Stanowisko badawcze i metodyka pomiarów}

Podstawowymi elementami stanowiska pomiarowego wykorzystanego w badaniach są: stół probierczy Bosch EPS-815 wraz z zespołem pomiaru dawki paliwa Bosch KMA 822 z wymiennikiem ciepła, szyna wysokiego ciśnienia oraz wtryskiwacz sterowany elektronicznie. Paliwo wtryskiwane było do specjalnej komory wypełnionej paliwem, która umożliwiała obserwację strugi wtryskiwanego paliwa. Za pomocą systemu wizualizacyjnego AVL Visioscope filmowano wtrysk paliwa do komory pomiarowej z rozdzielczością kątową wynoszącą $0,1^{\circ}$ obrotu wałka pompy. Schemat stanowiska przedstawiono na rys. 1.

Zasadniczym celem badań było określenie wielkości dawki paliwa w zależności od strategii jej podziału. Zmianom podlegały odległości pomiędzy początkami sygnałów sterujących pracą wtryskiwacza oraz czasy jego otwarcia. Badania przeprowadzono dla podziału dawki paliwa na dwie części (dawka pilotowa i dawka główna). Przyjęty sumaryczny czas wtrysku paliwa tinj wynosił, w zależności od programu pomiarów, 1,0 lub 3,0 ms, przy czym przez czas wtrysku należy rozumieć czas trwania sygnału sterującego otwarciem wtryskiwacza. Odległości między początkami sygnałów sterujących wtryskiwaczem są parametrami ustawianymi i nie należy ich utożsamiać z rzeczywistymi początkami wtrysku paliwa. Problematyka związana z wielofazowością wtrysku i rzeczywistym początkiem wtrysku stanowi kontynuację badań przedstawionych w pracach $[2,4,5,6,8]$.

Każda seria badań prowadzona była przy ustalonej temperaturze wtryskiwanego paliwa Tinj w komorze pomiarowej, ciśnieniu paliwa prail w szynie paliwowej oraz częstotliwości pracy wtryskiwacza, która wynikała z prędkości obrotowej n wałka pompy wysokiego ciśnienia.

Wartości parametrów związanych z wtryskiem paliwa zostały ujęte na rysunkach prezentujących wyniki badań. Natomiast symbole przyjęte do oznaczania parametrów strategii wtrysku przedstawiono na rys. 2 .

Na podstawie analizy sfilmowanych przebiegów procesu wtrysku paliwa do komory pomiarowej określono precyzyjnie rzeczywiste początki wtrysku. Dla wtrysku dwufazowego 


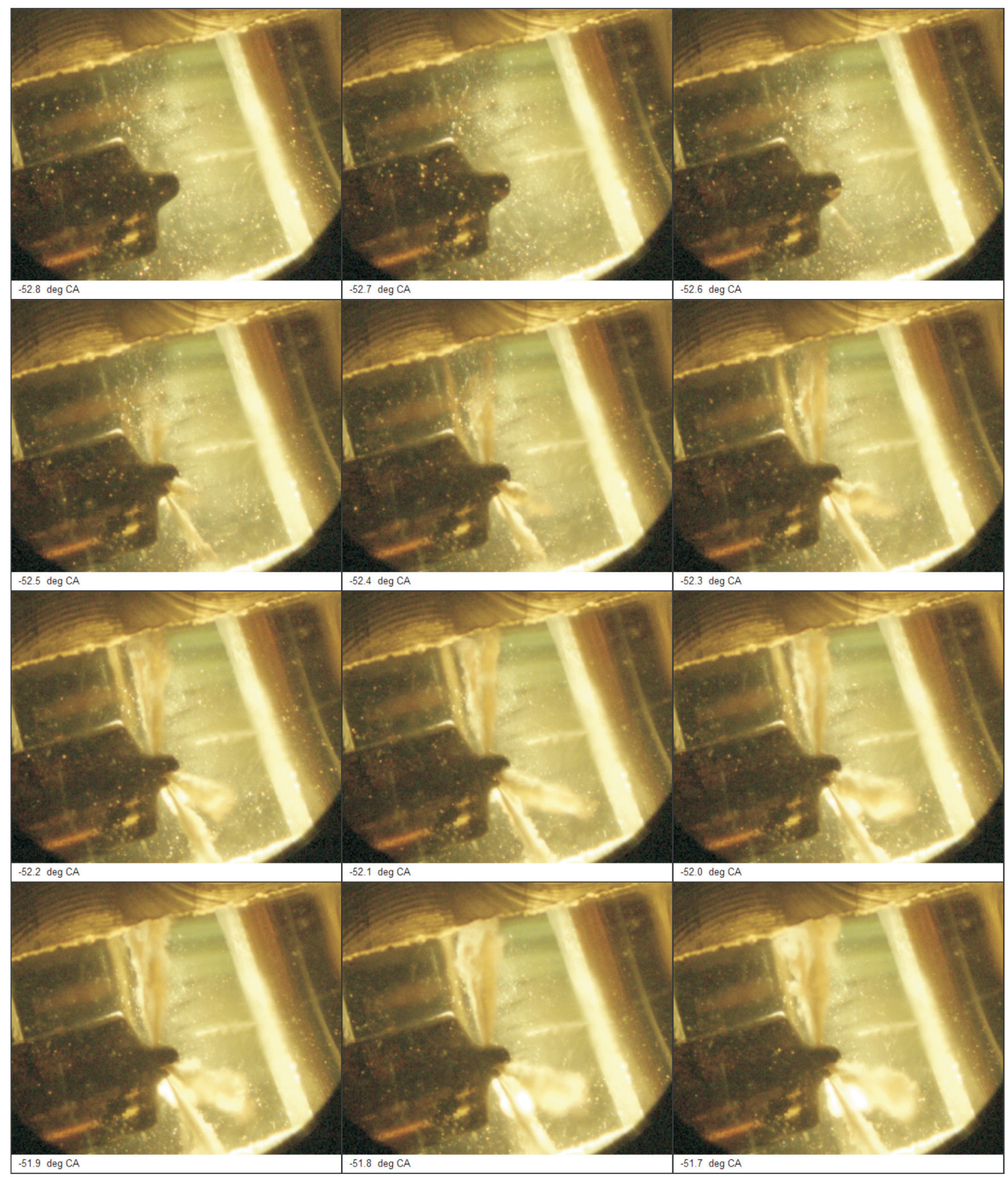

Fig. 3. Course of injected fuel stream ( $\mathrm{p}_{\text {rail }}=100 \mathrm{MPa}$ adjusted total injection duration $\mathrm{t}_{\mathrm{inj}}=1.0 \mathrm{~ms}, \mathrm{n}=600 \mathrm{rpm}$, injector Fiat) Rys. 3. Rozwój strugi wtryskiwanego paliwa ( $p_{\text {rail }}=100 \mathrm{MPa}$, czas wtrysku $t_{\text {wrr }}=1 \mathrm{~ms}, n=600 \mathrm{obr} / \mathrm{min}$, wtryskiwacz Fiat

$5 \mathrm{~mm}^{3} /$ injection) and its value does not depend on the rail pressure (Fig. 5).

The ambiguous character of the fuel dose change results from a random wave phenomena in the injection system which could result in the opening of the injector for both lower and higher values of pressure prail in relation to the adjusted value. wyznaczono zmiany rzeczywistego początku wtrysku dawki zasadniczej, przyjmując za punkt wyjściowy początek wtrysku tylko dawki zasadniczej (bez dawki pilotującej). Na rysunku 3 przedstawiono przykładowe zdjęcia rozwoju strugi paliwa.

W badaniach wykorzystano wtryskiwacze firmy Bosch z silników Renault G9T (o oznaczeniu 445010 343-01) 


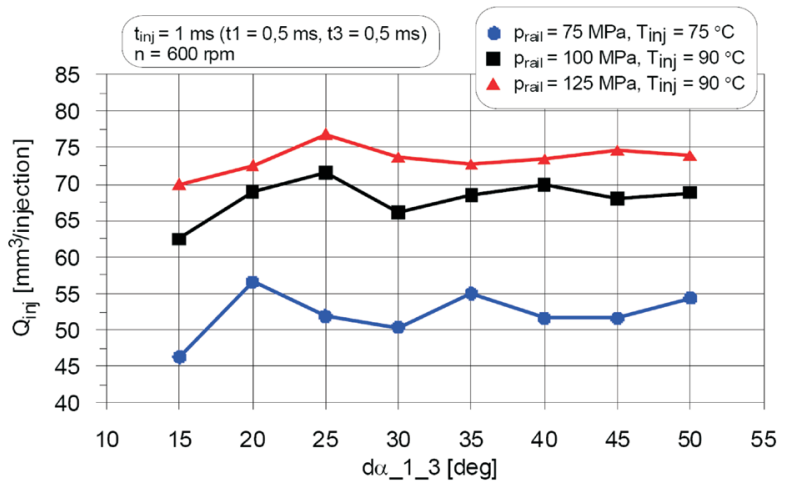

Fig. 4. The effect of distance between onsets of the pilot and the main injections $d \alpha \_1 \_3$ and various rail pressures prail on the fuel dose $\mathrm{Q}_{\mathrm{inj}}$

(adjusted total injection duration $\mathrm{t}_{\text {inj }}=1.0 \mathrm{~ms}$, injector Renault)

Rys. 4. Wpływ odległości pomiędzy poczatkiem wtrysku pilotowego i głównego da_1_3 oraz różnych ciśnień paliwa $w$ szynie prail na wielkość dawki paliwa $Q_{i n j}$ (ustawiony sumaryczny czas wtrysku $t_{i n j}=1,0 \mathrm{~ms}$, wtryskiwacz Renault)

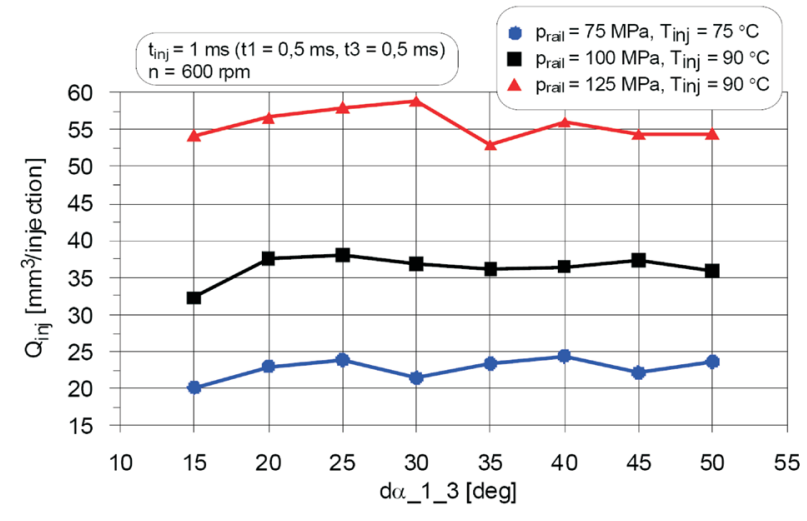

Fig. 5. The effect of distance between onsets of the pilot and the main injections $d \alpha \_1 \_3$ and various rail pressures prail on the fuel dose $Q_{i n j}$ (adjusted total injection duration $\mathrm{t}_{\mathrm{inj}}=1.0 \mathrm{~ms}$, injector Fiat)

Rys. 5. Wpływ odległości pomiędzy poczatkiem wtrysku pilotowego i głównego da_1_3 oraz różnych ciśnień paliwa w szynie prail na wielkość dawki paliwa $Q_{i n j}$ (ustawiony sumaryczny czas wtrysku $t_{i n j}=1,0 \mathrm{~ms}$, wtryskiwacz Fiat)



Fig. 6. The effect of distance between onsets of the pilot and the main injections d $\alpha \_1 \_3$ and various rail pressures prail on the fuel dose $Q_{\text {inj }}$ (adjusted total injection duration $\mathrm{t}_{\text {inj }}=3.0 \mathrm{~ms}$, injector Renault)

Rys. 6. Wptyw odległości pomiędzy początkiem wtrysku pilotowego i głównego da_1_3 oraz różnych ciśnień paliwa $w$ szynie prail na wielkość dawki paliwa $Q_{i n j}$ (ustawiony sumaryczny czas wtrysku $t_{i n j}=3,0 \mathrm{~ms}$, wtryskiwacz Renault) oraz Fiat Multijet 1.3 (445 010 083). Wtryskiwacze współpracowały z pompami wysokociśnieniowymi, takimi jakie stosowane są w tych silnikach, czyli odpowiednio CR/CP1S3/L70/10-1V i CR/CP1K3/R55/10-S. Wtryskiwacze były sterowane sterownikiem, opracowanym w Zakładzie Pojazdów Samochodowych i Silników Spalinowych Politechniki Rzeszowskiej, pozwalającym na podział dawek oraz zmiany ich wielkości i położenia kątowego w szerokim zakresie. Szczegółowy opis sterownika i kompletacji układu wtryskowego przedstawiono w pracy [1].

\section{Wyniki badań}

Na rysunkach 4 i 5 przedstawiono przykładowe wyniki badań określające wpływ odległości pomiędzy początkiem wtrysku pilotowego i głównego d $\alpha \_1 \_3$ na wielkość sumarycznej dawki paliwa Qinj dla różnych ciśnień paliwa w szynie prail i przy prędkości obrotowej pompy $n=600 \mathrm{obr} / \mathrm{min}$. W tym przypadku, przy podziale dawki na dwie części, całkowity czas wtrysku wynosił 1,0 ms (dawka pilotowa $0,5 \mathrm{~ms}$ i dawka główna 0,5 ms). Dla wtryskiwacza Renault (rys. 4), największe wahania dawki paliwa występują dla mniejszych odległości pomiędzy dawkami i przy niższych ciśnieniach. Dla dwóch różnych wartości odległości dawki pilotującej i zasadniczej (15 i 20º), przy ciśnieniu w szynie wynoszącym $75 \mathrm{MPa}$, różnica w wartościach uzyskanej dawki paliwa wyniosła ponad $10 \mathrm{~mm}^{3} /$ wtrysk (rys. 4). Nieco mniejsze zmiany dawki występują dla wtryskiwacza Fiat (ok. $5 \mathrm{~mm}^{3} /$ wtrysk), a ich poziom jest zbliżony, niezależnie od ciśnienia paliwa w szynie (rys. 5). Niejednoznaczny charakter zmian dawki paliwa wynika z losowych zjawisk falowych zachodzących w układzie wtryskowym, co powoduje, że otwarcie wtryskiwacza następować może zarówno dla mniejszych, jak i większych wartości ciśnienia prail w stosunku do wartości wyregulowanej.

Na rysunkach 6 i 7 przedstawiono wyniki badań w układzie podobnym jak na rys. 4 i 5; różnica polega na zastosowaniu większej dawki paliwa. W tym przypadku sumaryczny czas otwarcia wtryskiwacza wynosił $\mathrm{t}_{\mathrm{inj}}=3,0 \mathrm{~ms}$ (dla dawki pilotowej $\mathrm{t}_{1}=0,5 \mathrm{~ms}$ i dla dawki głównej $\mathrm{t}_{3}=2,5 \mathrm{~ms}$ ). Podobnie

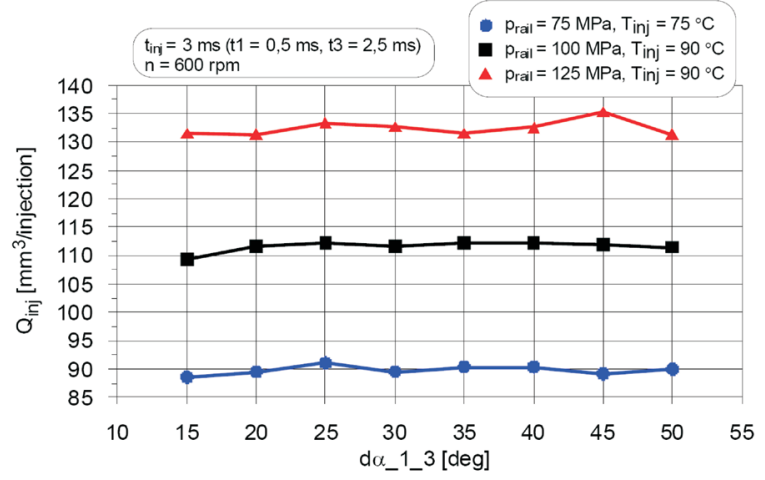

Fig. 7. The effect of distance between onsets of the pilot and the main injections $d \alpha \_1 \_3$ and various rail pressures prail on the fuel dose $Q_{\text {inj }}$ (adjusted total injection duration $\mathrm{t}_{\mathrm{inj}}=3.0 \mathrm{~ms}$, injector Fiat)

Rys. 7. Wplyw odległości pomiędzy początkiem wtrysku pilotowego i głównego da_1_3 oraz różnych ciśnień paliwa $w$ szynie prail na wielkość dawki paliwa $Q_{i n j}$ (ustawiony sumaryczny czas wtrysku $t_{i n j}=3,0 \mathrm{~ms}$, wtryskiwacz Fiat) 




Fig. 8. The effect of distance between onsets of the pilot and the main injections $d \alpha \_1 \_3$ and various rail pressures $\mathrm{p}_{\text {rail }}$ on the relative changes of the actual injection onset for the main dose $\Delta \mathrm{d} \alpha 3$ (adjusted total injection duration $\mathrm{t}_{\text {inj }}=3.0 \mathrm{~ms}, \mathrm{n}=600 \mathrm{rpm}$, injector Fiat)

Rys. 8. Wplyw odległości pomiędzy początkiem wtrysku pilotowego

i głównego da_1_3 oraz różnych ciśnień paliwa w szynie $p_{\text {rail }} n a$ względne zmiany rzeczywistego początku wtrysku dawki głównej $\Delta d \alpha \_3$

(ustawiony sumaryczny czas wtrysku $t_{i n j}=3,0 \mathrm{~ms}, n=600 \mathrm{obr} / \mathrm{min}$, wtryskiwacz Fiat)

In Fig. 6 and 7 in a similar order, as in Fig. 4 and 5 the test results have been presented - in this case the difference depends on a larger fuel dose. In this case the total duration of the injection amounted to $t_{\text {inj }}=3.0 \mathrm{~ms}$ (for the pilot dose it was $\mathrm{t}_{1}=0.5 \mathrm{~ms}$ and for the main dose it was $\mathrm{t}_{3}=2.5 \mathrm{~ms}$ ). As in the previously analyzed case a certain stabilization of the fuel dose for larger angle intervals between the pilot dose and the main dose can be observed. It particularly concerns the injector fitted in Renault. It has also been shown that for the lowest pressure value $\left(\mathrm{p}_{\text {rail }}=75 \mathrm{MPa}\right)$ the dose fluctuations are considerably lower than for the lower total dose $\left(\mathrm{t}_{\mathrm{inj}}=1.0 \mathrm{~ms}\right.$, compare Fig. 4). For the Fiat injector a smoother effect of the pressure on the fuel dose can be observed than for the Renault injector.

On the basis of the visualization tests for the Fiat injector it has been found, that the real injection onset for the main dose, at the pump speed amounting to $600 \mathrm{rpm}$, in the examined range practically doesn't depend on the position of the pilot dose over d $\alpha \_1 \_3=20 \mathrm{deg}$. The largest changes of the actual injection onset for the main dose occur for small intervals between the pilot and the main doses. For high speed $(2000 \mathrm{rpm})$ the range of these changes is distinct and amounts to more than $2.5 \mathrm{deg}$ (Fig. 9). For the engine this value makes significant changes of the actual onset of the injection (above $5 \operatorname{deg} \mathrm{CA}$ ). The largest changes for this speed also occur at small angle intervals between the pilot and the main doses (15-25 deg). For these distances, the distortion of the work of the injector causes an earlier opening of the injector. It might be the result of the needle inertia resulting from the injected fuel dose and the changes of the pressure under and over the needle cause an earlier lift of the needle as opposed to the injection realized without the pilot dose.

\section{Conclusions}

As it results from the analysis of the obtained results, the change of the mutual angle intervals of the individual parts of

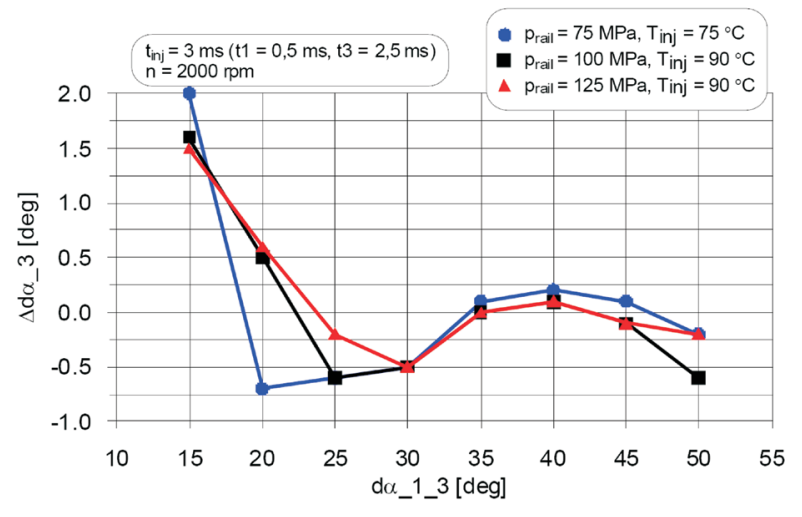

Fig. 9. The effect of distance between onsets of the pilot and the main injections $\mathrm{d} \alpha \_1 \_3$ and various rail pressures $\mathrm{p}_{\text {rail }}$ on the relative changes of the actual injection onset for the main dose $\Delta \mathrm{d} \alpha \_3$ (adjusted total injection duration $\mathrm{t}_{\mathrm{inj}}=3.0 \mathrm{~ms}, \mathrm{n}=2000 \mathrm{rpm}, \overline{\text { injector Fiat) }}$

Rys. 9. Wptyw odległości pomiędzy początkiem wtrysku pilotowego i głównego da 13 oraz różnych ciśnień paliwa w szynie p $p_{\text {il }}$ na zmiany względne zmiany rzeczywistego początku wtrysku dawki głównej $\Delta d \alpha \_3$ (ustawiony sumaryczny czas wtrysku $t_{i n j}=3,0 \mathrm{~ms}, n=2000 \mathrm{obr} / \mathrm{min}$, wtryskiwacz Fiat)

jak we wcześniej analizowanym przypadku, można zaobserwować pewną stabilizację dawki paliwa dla większych odległości kątowych pomiędzy dawką pilotową a główną (dotyczy to szczególnie wtryskiwacza Renault). Widać również, że dla najmniejszej wartości ciśnienia $\left(\mathrm{p}_{\text {rail }}=75\right.$ $\mathrm{MPa}$ ), wahania dawki są znacznie mniejsze niż miało to miejsce dla niższej dawki sumarycznej $\left(\mathrm{t}_{\mathrm{inj}}=1,0 \mathrm{~ms}\right.$, por. rys. 4). Dla wtryskiwacza Fiat zaobserwowano bardziej równomierny wpływ ciśnienia na wielkość dawki paliwa niż dla wtryskiwacza Renault.

Na podstawie badań wizualizacyjnych przeprowadzonych dla wtryskiwacza Fiat stwierdzono, że rzeczywisty początek wtrysku paliwa dawki zasadniczej dla prędkości obrotowej wałka pompy $600 \mathrm{obr} / \mathrm{min}$, nie zależy od położenia dawki pilotującej powyżej d $\alpha \_1 \_3=20$ stopni $\mathrm{w}$ rozpatrywanym zakresie (rys. 8). Największe zmiany rzeczywistego początku wtrysku dawki zasadniczej występują dla małych odległości pomiędzy dawką pilotującą i zasadniczą. Dla większych prędkości obrotowych (2000 obr/min) zakres tych zmian jest już widoczny i wynosi ponad 2,5 (rys. 9), co w odniesieniu do silnika daje już znaczące zmiany rzeczywistego początku wtrysku dawki zasadniczej (ponad $5^{\circ} \mathrm{OWK}$ ). Największe zmiany, dla tej prędkości, również występują przy małych odległościach kątowych dawki pilotującej i zasadniczej (15-25o obrotu wałka pompy). Dla tych odległości zakłócenia $\mathrm{w}$ pracy wtryskiwacza powodują wcześniejsze jego otwarcie. Wynikać to może z faktu, że iglica jest jeszcze w ruchu spowodowanym wtryskiwaną dawką pilotującą, a występujące zmiany ciśnienia pod iglicą i nad nią powodują jej wcześniejszy wznios w stosunku do wzniosu dla wtrysku realizowanego bez dawki pilotującej.

\section{Wnioski}

Przy realizacji wtrysku wielofazowego, jak wynika z analizy uzyskanych wyników, zmiana wzajemnego położenia kątowego poszczególnych części dawki powoduje odchyłki 
the dose causes deviations during fuel dosage for both tested injectors and decreases the accuracy of the control. It results from a large fluctuation of the pressure in the injection pipe, which occurs even after the injection of small doses. Because, between the pilot and the main doses small angle intervals occur, the pressure wave cannot attenuate and the occurring pressure fluctuations cause a change of the dose even though the total dose duration is equal. Dosage changes result from the points on the pressure wave where the injector opening occurs. The pressure fluctuations can amount to approximately $40 \mathrm{MPa}$ and such large changes cause the changing of the actual injection onset for the main dose. Taking into consideration that the length of the wave depends on many factors (for example fuel properties) these deviations can be difficult to compensate in the controller.

For high pump speed the changes of the actual injection onset for the main dose can amount to as many as several degrees, particularly for small intervals between the individual doses (an earlier opening of the injector occurs).

To consolidate, it should be stated that during the operation of a common rail system considerable deviations of the fuel dosage as well as the actual injection onset may occur, which may have an adverse effect on the emissions and functional parameters of the compression ignition engines.

Artykut recenzowany

\section{Bibliography/Literatura}

[1] Balawender K.: Wpływ wybranych parametrów regulacyjnych procesu wtrysku na emisję cząstek stałych w silniku wysokoprężnym typu DI. Rozprawa doktorska, Rzeszów 2007.

[2] Balawender K., Kuszewski H., Lejda K, Ustrzycki A.: The influence of mutual angle position of main, pilot and preinjection dose on fuel dosing in common rail system. Journal of POLISH CIMAC - Energetics Aspects, Vol. 3, No. 1, Gdańsk 2008.

[3] Balawender K., Kuszewski H., Lejda K, Ustrzycki A.: The effect of angle position of main, pilot and preinjection fuel dose on nox formation in compression ignition engine with Common Rail system. Journal of KONES, Powertrain and Transport, Vol. 15, No. 3/2008.

[4] Kuszewski H., Ustrzycki A.: Badania procesu dawkowania paliwa w zasobnikowym układzie wtryskowym. Вісник Національного транспортного університету, No. 14/2007, Kijów 2007.

Mr. Krzysztof Balawender, DEng. - doctor in the Faculty of Mechanical Engineering and Aeronautics at Rzeszow University of Technology.

Dr inż. Krzysztof Balawender-adiunkt na Wydziale Budowy Maszyn i Lotnictwa Politechniki Rzeszowskiej. e-mail:kbalawen@prz.edu.pl



Mr. Hubert Kuszewski, DEng. - doctor in the Faculty of Mechanical Engineering and Aeronautics at Rzeszow University of Technology.

Dr inż. Hubert Kuszewski-adiunkt na Wydziale Budowy Maszyn i Lotnictwa Politechniki Rzeszowskiej.

e-mail:hkuszews@prz.edu.pl w dawkowaniu paliwa dla obu badanych wtryskiwaczy, zmniejszając precyzję sterowania. Wynika to z dużych wahań ciśnienia $\mathrm{w}$ przewodzie wtryskowym, jakie występują po wtryśnięciu nawet niewielkich dawek paliwa. Ponieważ pomiędzy dawką pilotującą a zasadniczą występują stosunkowo niewielkie odległości kątowe, to fala ciśnienia nie zdąży się wythumić i występujące pulsacje ciśnienia powodują zmiany dawki, pomimo że sumaryczny czas jest jednakowy. Zmiany dawkowania zależą od tego, $w$ jakim punkcie fali następuje otwarcie wtryskiwacza. Ponieważ z badań wynika, że wahania ciśnienia mogą wynosić nawet ponad $40 \mathrm{MPa}$, to tak duże zmiany powodują również zmiany rzeczywistego początku wtrysku dawki zasadniczej. Stąd też, biorąc pod uwagę, że długość fali zależy od wielu czynników (m.in. właściwości paliwa), odchylenia te mogą być trudne do skompensowania w charakterystykach sterownika. Dla dużych prędkości obrotowych zmiany rzeczywistego kąta początku wtrysku dawki zasadniczej mogą wynosić nawet kilka stopni, szczególnie dla małych odległości pomiędzy poszczególnymi dawkami (następuje wcześniejsze otwarcie wtryskiwacza).

Podsumowując należy stwierdzić, że w czasie pracy układu common rail mogą występować w określonych warunkach odchylenia zarówno w wielkości odmierzanej dawki paliwa, jak i rzeczywistego początku wtrysku, co może negatywnie wpływać na poziom emisji szkodliwych związków w spalinach oraz parametry użytkowe silnika wysokoprężnego.
[5] Kuszewski H., Ustrzycki A.: Metodyka określania rzeczywistego początku wtrysku paliwa w układach zasilania silników wysokoprężnych. Prace Zachodniego Centrum Akademii Transportu Ukrainy, Lwów 2006.

[6] Kuszewski H., Ustrzycki A.: Wpływ parametrów pracy zasobnikowego układu wtryskowego na rzeczywisty początek wtrysku paliwa. Polskie Towarzystwo Naukowe Silników Spalinowych, Silniki Spalinowe, ,Mixture Formation, Ignition \& Combustion", 2007-SC2, 2007.

[7] Praca zbiorowa: Zasobnikowe układy wtryskowe Common Rail. Informatory techniczne Bosch. WKiE, Warszawa 2005.

[8] Ustrzycki A., Kuszewski H.: Badania początku wtrysku paliwa w układzie wtryskowym typu Common Rail. Materiały XVII konferencji międzynarodowej SAKON'06 nt. „Metody obliczeniowe i badawcze w rozwoju pojazdów samochodowych i maszyn roboczych samojezdnych. Zarządzanie i marketing w motoryzacji”, Rzeszów 2006.

Mr. Kazimierz Lejda, DSc., DEng. - Professor in the Faculty of Mechanical Engineering and Aeronautics at Rzeszow University of Technology.

Dr hab. inż. Kazimierz Lejda - profesor na Wydziale Budowy Maszyn i Lotnictwa Politechniki Rzeszowskiej. e-mail:klejda@prz.edu.pl

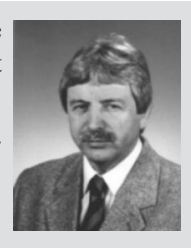

Mr. Adam Ustrzycki, DEng. - doctor in the Faculty of Mechanical Engineering and Aeronautics at Rzeszow University of Technology.

Dr inż. Adam Ustrzycki - adiunkt na Wydziale Budowy Maszyn i Lotnictwa Politechniki Rzeszowskiej.

e-mail:austrzyc@prz.edu.pl

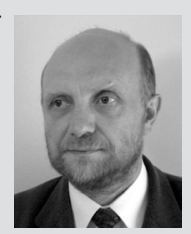

